\title{
Extreme pointer years in tree-ring records of Central Spain as evidence of climatic events and the eruption of the Huaynaputina Volcano (Peru, 1600 AD)
}

\author{
M. Génova \\ Escuela de Ingeniería Técnica Forestal, Universidad Politécnica de Madrid, Madrid, Spain \\ Correspondence to: M. Génova (mar.genova@upm.es)
}

Received: 28 July 2011 - Published in Clim. Past Discuss.: 8 December 2011

Revised: 13 March 2012 - Accepted: 19 March 2012 - Published: 13 April 2012

\begin{abstract}
The study of pointer years of numerous treering chronologies of the central Iberian Peninsula (Sierra de Guadarrama) could provide complementary information about climate variability over the last $405 \mathrm{yr}$. In total, 64 pointer years have been identified: 30 negative (representing minimum growths) and 34 positive (representing maximum growths), the most significant of these being 1601, 1963 and 1996 for the negative ones, and 1734 and 1737 for the positive ones. Given that summer precipitation was found to be the most limiting factor for the growth of Pinus in the Sierra de Guadarrama in the second half of the 20th century, it is also an explanatory factor in almost $50 \%$ of the extreme growths. Furthermore, these pointer years and intervals are not evenly distributed throughout time. Both in the first half of the 17th and in the second half of 20th, they were more frequent and more extreme and these periods are the most notable for the frequency of negative pointer years in Central Spain. The interval 1600-1602 is of special significance, being one of the most unfavourable for tree growth in the centre of Spain, with 1601 representing the minimum index in the regional chronology. We infer that this special minimum annual increase was the effect of the eruption of Huaynaputina, which occurred in Peru at the beginning of 1600 AD. This is the first time that the effects of this eruption in the tree-ring records of Southern Europe have been demonstrated.
\end{abstract}

\section{Introduction}

In recent decades a considerable number of studies have been carried out about the climate variability of the Iberian Peninsula over the past millennium from numerous points of view. Starting with the pioneering studies of Fontana
Tarrats (1971-1977) about the indirect registers of climatic events derived from very diverse documentary sources (mostly unpublished) and in many different regions, which were compiled and summarised by Font Tullot (1988), the knowledge of the past climate of the Iberian Peninsula from documentary studies has grown considerably (Martín-Vide and Barriendos, 1995; Rodrigo et al., 1999; Barriendos, 1997; Vicente-Serrano and Cuadrat, 2007; Rodrigo and Barriendos, 2008; Domínguez-Castro et al., 2008, 2010). Sometimes, this documentary data have been compared with other proxies, mainly from dendroclimatic reconstructions (Manrique and Fernández-Cancio, 2000; Saz, 2003; VicenteSerrano and Cuadrat, 2007; Génova, 2009). Unlike what is habitual in many other regions of the Northern Hemisphere, these reconstructions are not very abundant in Spain.

Dendroclimatic studies are valuable for examining the time distribution of climate events, because the length of tree-ring series provides an extended context to assess such changes. One of the features to assess these changes is pointer years: years with markedly wider or narrower treering width compared to neighbouring tree rings. In general, the study of the relationship between pointer years and climatic factors has represented only a marginal interest in dendrochronology, especially with the growing application of information technology, because this relationship is not easy to define. Nevertheless, in certain cases and using qualitative techniques, it has indeed been demonstrated that the pointer years, which present themselves over wide geographical areas, tend to be associated with determinate macro-climatic events (LaMarche and Hirschboeck, 1984; Scuderi, 1990; Briffa et al., 1998; Knapp et al., 2002; Hantemirov et al., 2004; Neuwirth et al., 2007). Furthermore, pointer years are also used to support the correct dating in historical or

Published by Copernicus Publications on behalf of the European Geosciences Union. 
archaeological material (Schweingruber, 1990; Schweingruber et al., 1990; Querrec et al., 2009; Génova et al., 2011).

The principal aim of this paper is to provide new insight, based on tree rings, into the climate variability of the central Iberian Peninsula (Sierra de Guadarrama) over the last $405 \mathrm{yr}$. Based on the pointer year analysis of 15 chronologies from 253 trees, the paper provides a more robust characterisation of drought variability in Spain where precipitation series longer than one century are very rare (Domínguez-Castro et al., 2010), and to increase the information about extreme climate events.

The interpretation of the pointer years depends on their position in the dendrochronological sequences and on their significance, whether individual, local or regional (Schweingruber et al., 1990), although at the regional level only the climatic interpretation is possible. The suitability of pointer years for the determination of extreme climatic events has already been demonstrated (Kienast et al., 1987; Schweingruber, 1990; Meyer, 1999; Génova, 2000; Rolland et al., 2000; Neuwirth et al., 2007). Evident climatic interpretations such as severe winter frosts, unusual summer droughts, or excessive cold springs can explain most of the negative pointer years. Other authors have related negative pointer years to macro-climatic events on a global scale, such as those derived from the major volcanic eruptions (LaMarche and Hirschboeck, 1984; Scuderi, 1990; Jones et al., 1995; Briffa et al., 1998; Hantemirov et al., 2004). Conversely, most positive growth responses are caused by a local combination of favourable ecological factors rather than simple extreme events (Rolland et al., 2000). In this context the analysis set forth in Génova (2000) has been brought up-to-date and completed, with a global evaluation of the pointer years detected in different sites of Central Spain. The objective has been to develop a record of pointer years of regional significance through a thorough analysis that is narrowly-focused but of great reliability.

\section{Material and methods}

\subsection{Sampling sites and chronologies}

The Sierra de Guadarrama forms part of the eastern half of the Central System in the centre of the Iberian Peninsula, situated between the Sierras of Gredos and Ayllón. It extends in a southwest-northeast direction in the Spanish provinces of Madrid, Segovia and Ávila. This Sierra extends approximately $80 \mathrm{~km}$ in length, and its highest peak is the Peñalara, at $2428 \mathrm{~m}$. The rocky substratum is quite varied, with a great deal of granite in the western parts, while in the centre and north-east there is a predominance of rock with a certain degree of metamorphism, such as gneiss. It is one of the most important forested areas of continental Spain, with a clear predominance, especially above $1000 \mathrm{~m}$ altitude, of one of the best representations of Pinus sylvestris forest. By the end of the 19th and beginning of the 20th centuries the area was practically deforested, especially on its southerly slopes, due to repeated fires, war and grazing and the large-scale extraction of wood had suffered since the Middle Ages. Consequently, the greater part of the pine woods derives from successive re-afforestation affected from that time on (Bauer, 1980; Rojo and Montero, 1996; Martínez García and Costa, 2001). Nevertheless, the northern slopes still preserve some of the finest natural Scots pine forests that exist in Spain. The Valsaín Forest in Segovia, for example, is one of the few state-owned forests in Spain, and has been managed since the 18 th century. Since then, it has been drawn upon as a source of timber without interruption until the present day, and has been kept in an excellent state of conservation.

The dendrochronological samples of Pinus sylvestris have been drawn principally from the highest areas and the northern slopes, availing of what remains of the original forest mass that still preserves some aged individual specimens. In the course of the various studies we have carried out in the region over the last decades, we have established the existence of some specimens that are over $500 \mathrm{yr}$ old, the maximum known for this species so far in the Iberian Peninsula (Génova, 2000).

Moreover, some small pine forests and relictic stands of Pinus nigra have established themselves (occasionally mixed with Pinus sylvestris or Pinus pinaster) in the western area of Sierra de Guadarrama, growing on the hillsides above the Jarosa reservoir (Madrid), between 1200 and $1600 \mathrm{~m}$ (Regato et al., 1992). These populations form part of the most westerly natural distribution of this taxon in the world. Even though these trees display mainly narrow diametres and have reduced and flat crowns, they are the oldest known in the Sistema Central, some of them being more than $500 \mathrm{yr}$ old (Génova and Fernández-Cancio, 1998/1999, Génova, 2000).

The tree-ring chronologies analysed here are elaborated on the basis of data from 15 sites in the Sierra de Guadarrama: 13 sites correspond to populations of Pinus sylvestris and 2 to populations of $P$. nigra subsp. salzmannii (see Fig. 1). The data, derived both from sites studied by various authors and published in the "International Tree-Ring Data Bank" (ITRDB) - 8 sites (see Table 1) - and from other sites studied in Génova et al. (1993), also published in the ITRDB (Pedriza and Riscopol), together with others studied in Génova and Fernández-Cancio (1998/1999) (Jarosa, subsequently revised for this paper) or in Génova (2000) (Peñota, Cotos, Sietepicos) and, most recently (Valsaín), studied in Benso (2007) and Génova et al. (2009).

The 13 sites of Pinus sylvestris are distributed in a broad range in both altitudinal (1385 $\mathrm{m}-2050 \mathrm{~m}$ ) and spatial (8 sites with $\mathrm{N}$ or N-NE slopes and 5 with S slopes) parameters. As such, they are representative of the large surface area occupied by this pine in the region. By contrast, the altitudinal and spatial range of the sites of Pinus nigra analysed is much more limited (both are located on E slopes and are very close to each other, between $1400 \mathrm{~m}$ and $1600 \mathrm{~m}$ altitude), although 
Table 1. General Characteristics of the chronologies developed in Sierra de Guadarrama. Pisy: Pinus sylvestris, Pini: Pinus nigra.

\begin{tabular}{|c|c|c|c|c|c|c|c|c|c|c|c|}
\hline Site name & Site code & Species & $\begin{array}{l}\text { Latitude/ } \\
\text { longitude }\end{array}$ & $\begin{array}{l}\text { Elevation } \\
\text { (ma.s.l.) }\end{array}$ & Aspect & $\mathrm{Nt}^{1}$ & $\mathrm{Ns}^{2}$ & $\mathrm{MS}^{3}$ & $\mathrm{IT}^{4}$ & Time span & Author/s \\
\hline Puerto de Navacerrada & NAV & Pisy & $40^{\circ} 48^{\prime} / 4^{\circ} 02^{\prime}$ & 2050 & $\mathrm{~N}$ & 13 & 24 & 0.22 & 0.488 & $1663-1977$ & $\begin{array}{l}\text { Bräker and Schweinegruber } \\
\text { (1984) (ITRDB) }\end{array}$ \\
\hline Guadarrama-Camorca & CAM & Pisy & $40^{\circ} 49^{\prime} / 4^{\circ} 03^{\prime}$ & 1550 & $\mathrm{~N}$ & 13 & 27 & 0.31 & 0.618 & $1726-1983$ & Richter (1988 (ITRDB) \\
\hline Guadarrama-Iniesto & INI & Pisy & $40^{\circ} 48^{\prime} / 3^{\circ} 59^{\prime}$ & 1800 & $\mathrm{~N}$ & 20 & 39 & 0.26 & 0.545 & $1749-1983$ & Richter (1988) (ITRDB) \\
\hline $\begin{array}{l}\text { Guadarrama-Loma } \\
\text { de Noruego }\end{array}$ & NOR & Pisy & $40^{\circ} 47^{\prime} / 3^{\circ} 58^{\prime}$ & 1950 & $\mathrm{~N}$ & 14 & 26 & 0.23 & 0.534 & $1661-1985$ & Richter (1988) (ITRDB) \\
\hline Guadarrama-Rascafria & RAS & Pisy & $40^{\circ} 48^{\prime} / 3^{\circ} 57^{\prime}$ & 1850 & $\mathrm{~N}$ & 10 & 23 & 0.24 & 0.556 & 1599-1984 & Richter (1988) (ITRDB) \\
\hline Navafría I & NA1 & Pisy & $40^{\circ} 59^{\prime} / 3^{\circ} 48^{\prime}$ & 1900 & $\mathrm{~S}$ & 18 & 30 & 0.22 & 0.532 & $1685-1992$ & Yuste (1994) (ITRDB) \\
\hline Navafría II & NA2 & Pisy & $40^{\circ} 58^{\prime} / 3^{\circ} 48^{\prime}$ & 1630 & $\mathrm{~S}$ & 13 & 24 & 0.24 & 0.626 & $1787-1992$ & Yuste (1994) (ITRDB) \\
\hline Navafría III & NA3 & Pisy & $40^{\circ} 58^{\prime} / 3^{\circ} 47^{\prime}$ & 1525 & $\mathrm{~S}$ & 10 & 28 & 0.24 & 0.692 & 1791-1992 & Yuste (1994) (ITRDB) \\
\hline Pedriza & PED & Pisy & $40^{\circ} 45^{\prime} / 3^{\circ} 53^{\prime}$ & 1650 & $\mathrm{~S}$ & 7 & 14 & 0.27 & 0.556 & $1715-1988$ & Génova et al. (1993) (ITRDB) \\
\hline Peñota & PEN & Pisy & $40^{\circ} 44^{\prime} / 4^{\circ} 06^{\prime}$ & 1650 & $\mathrm{~S}$ & 9 & 18 & 0.27 & 0.554 & $1763-1991$ & Génova (2000) \\
\hline Sietepicos & SIE & Pisy & $40^{\circ} 47^{\prime} / 4^{\circ} 01^{\prime}$ & 1650 & $\mathrm{~N}$ & 17 & 31 & 0.21 & 0.558 & $1527-1995$ & Génova (2000) \\
\hline Cotos & COT & Pisy & $40^{\circ} 48^{\prime} / 3^{\circ} 58^{\prime}$ & 1900 & $\mathrm{~N}$ & 14 & 29 & 0.22 & 0.515 & 1513-1994 & Génova (2000) \\
\hline Valsaín & VAL & Pisy & $40^{\circ} 50^{\prime} / 4^{\circ} 02^{\prime}$ & 1400 & $\mathrm{~N}-\mathrm{NE}$ & 43 & 81 & 0.29 & 0.549 & $1818-2005$ & Benso (2007) \\
\hline Riscopol & RIS & Pini & $40^{\circ} 40^{\prime} / 4^{\circ} 10^{\prime}$ & 1600 & E & 11 & 24 & 0.26 & 0.676 & $1523-1988$ & Génova et al. (1993) (ITRDB) \\
\hline Jarosa & JAR & Pini & $40^{\circ} 40^{\prime} / 4^{\circ} 09^{\prime}$ & 1400 & $\mathrm{E}$ & 15 & 27 & 0.27 & 0.590 & $1462-1992$ & $\begin{array}{l}\text { Génova and Fernández- } \\
(1998,1999), \text { revised } \\
\text { for this paper }\end{array}$ \\
\hline
\end{tabular}

${ }^{1} \mathrm{Nt}$ : number of trees, ${ }^{2}$ Ns: number of sequences, ${ }^{3}$ MS: mean sensitivity of raw sequences in each site, ${ }^{4}$ IT: intercorrelation of raw sequences in each site.

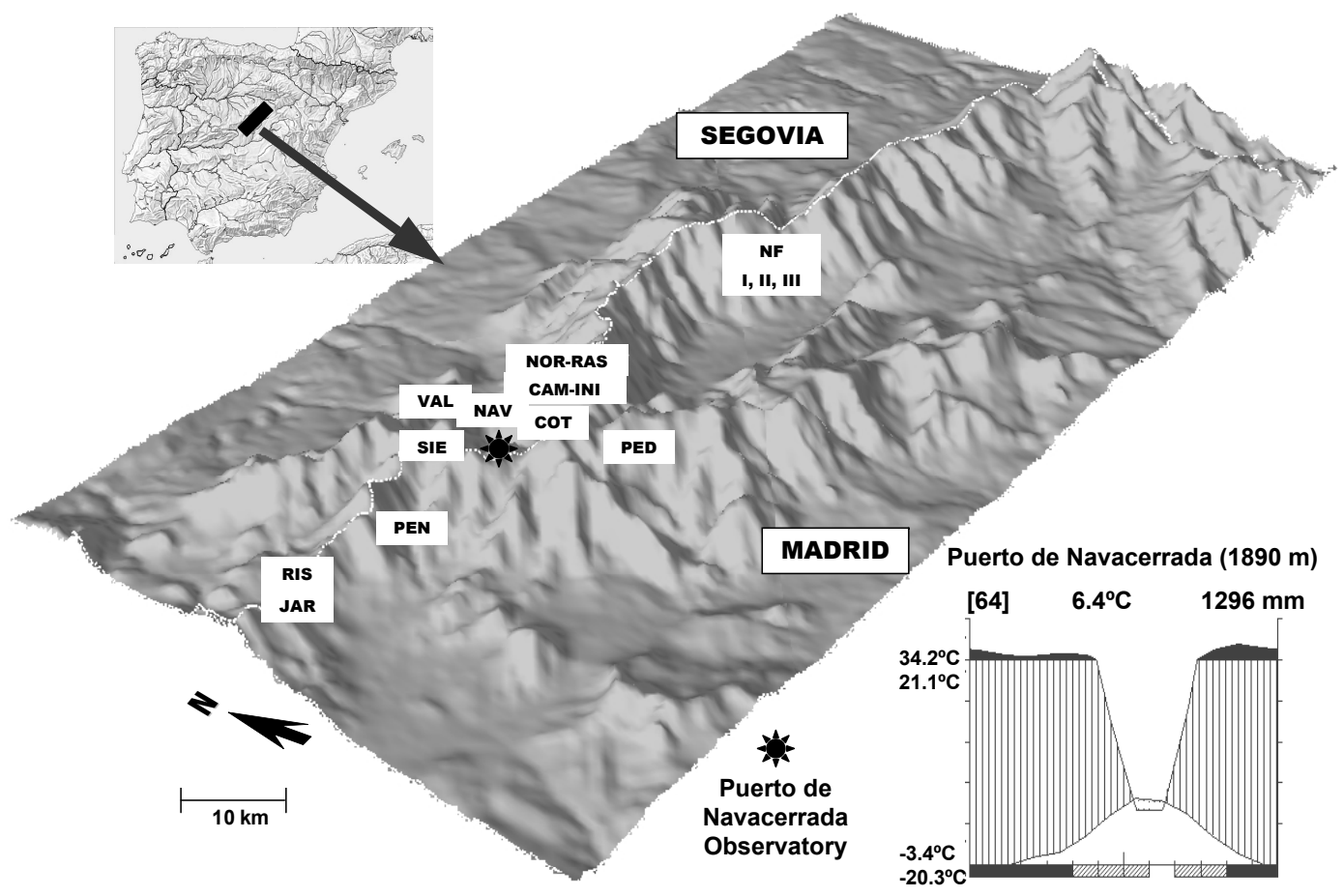

Fig. 1. Geographical position of the studied sites in the Sierra de Guadarrama (between the provinces of Segovia and Madrid, Spain), location of Puerto de Navacerrada meteorological observatory and climate diagram.

as such they are also representative of the sparse distribution of this taxon in the Sierra de Guadarrama.

The structure and density of the sampled pine sites range from dense and adult forest pine, managed for over a hundred years (Valsaín), or more recently (Navafría), forest pine situated in protected areas with majestic specimens (Sietepicos,
Cotos), through standing with adult specimens and natural regeneration, and/or deriving from re-afforestation in formations subject to frequent fires (Pedriza, Riscopol).

In each locality a very variable number of specimens were analysed. Generally speaking, the number of samples has increased as the techniques of statistical analysis have 
improved. Sample numbers have risen from a minimum of 14 synchronised growth series per site (Pedriza) through to a maximum of 81 (Valsaín). In total, we have to date 445 individual growth sequences from 227 trees (201 of $P i$ nus sylvestris and 26 of Pinus nigra) from the region. Local chronologies are very different as far as time span is concerned, ranging from a maximum of $530 \mathrm{yr}(1462-1992)$ in Jarosa, to a minimum of 187 yr (1818-2005) in Valsaín, even though they present similar mean sensitivity and intercorrelation values (see Table 1). In Fig. 2 the 15 local chronologies are presented, together with the number of individual sequences replicating each year, extending in total from 1462 to 2005 .

\subsection{Significance and reliability of the chronologies: compilation of the regional chronology}

Given that the available local chronologies present considerable variability with regard to the number of individual sequences and also the time span on which they are based, the representativity, significance and reliability of each chronology has been analysed using statistical techniques commonly employed in dendrochronological studies.

- Analysis of the principal components: a Principal Component Analysis (PCA) based on the correlation matrix was calculated for the common period 1818-1977 to evaluate the shared variance of the chronology network. The broken stick test was performed to determine the significance of the components (Holmes, 1992). The variance explained by the first principal component (PC1) was used as an indicator of the similarity among the chronologies.

- EPS (Expressed Population Signal): a value of EPS close to 0.85 constitutes an indicator of agreement of the sample chronology variance with that of the theoretical population chronology. Consequently, the value of this parameter means one reasonable choice suggested by Wigley et al. (1984) represents an acceptable level of chronology confidence.

- IT (Intercorrelation): relative intercorrelation compared with the other chronologies for the region in the different sub-periods studied by the COFECHA program (Holmes, 1999).

Finally, the periods that are well-monitored and sufficiently reliable in each local chronology have been used to produce a single average regional chronology.

\subsection{Extreme growth values and pointer years}

The study of extreme growth values in event years and their significance can be approached from different points of view and using different methodologies (Schweingruber et al., 1990; Meyer, 1999; Neuwirth et al., 2007; Elferts, 2007).

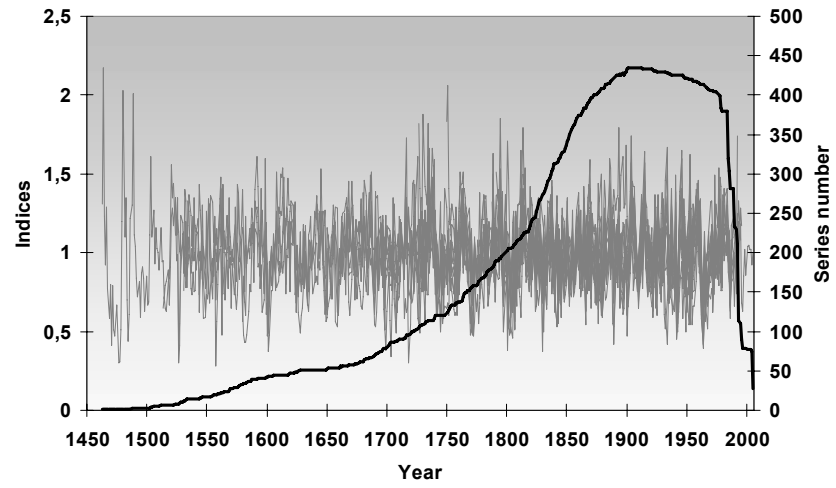

Fig. 2. Local chronologies developed in the Sierra de Guadarrama and the total number of tree-ring series in each year.

In this paper the criteria used in Génova (2000) have, in general, been followed, with the study being amplified to the positive extremes. Thus, the extreme years have been determined through the application of a double criterion:

- The values or indices of growth suppose a decrease or increase of more than $20 \%$, with respect to the average of that year and the year that comes immediately before it.

- In the indices of growth, a decrease or increase of one or more standard deviations is determined with respect to the chronological average.

Both criteria have been applied in a sequential manner. First of all, the individual growth series of each site has been analysed, and the extreme local years have been determined, considering that they are present in more than $75 \%$ of the series at least. Next, all of the local chronologies have been analysed following these same criteria, and finally, the regional chronology. In this way both the years that show evidence of an abrupt variation in growth with respect to what preceded them, and also the years of anomalous growth following on more gradual variations have been identified. This method allows a very detailed analysis of the local and regional significance of extreme growth values, even though it is more restrictive if compared with the methods used in other studies (for example, Rolland et al., 2000; Neuwirth et al., 2007; Andreu et al., 2007). In this respect it should be pointed out that the expression pointer year used in this paper is in accordance with the definition of Schweingruber (1990): "Concentration of cross-dated event years within a group of trees".

\subsection{Meteorological data and climate - tree growth relationship}

With the objective of explaining the climatic significance of pointer years, an analysis of the meteorological data for the area of study has been undertaken. In the Sierra de 
Guadarrama, only one station (Navacerrada) has been identified as having a long and continuous meteorological register. Furthermore, this station is representative of the climate of the central Iberian high mountains. The observatory is located in the vicinity of the Puerto de Navacerrada (province of Segovia), at $1890 \mathrm{~m}$ a.s.l., at $40^{\circ} 46^{\prime} 50^{\prime \prime}$ latitude $\mathrm{N}$ and $4^{\circ} 00^{\prime} 37^{\prime \prime}$ longitude W (Fig. 1). The meteorological record presents monthly precipitation and temperature data going back to 1943, indicating the typical characteristics of the climate of the high mountains of the Mediterranean, with a mean annual temperature of $6.4^{\circ} \mathrm{C}$. Frosts can be counted for from the months of November through to April, and probably in the other months also, with the exception of August. Precipitation is high throughout all months of the year (although November stands out as having the highest rainfall), except in July and August, which constitute a period that presents certain aridity. Mean annual precipitation is around $1296 \mathrm{~mm}$, while summer rainfall (combining July and August) is around $50 \mathrm{~mm}$, with the latter being even more irregular in its interannual variability. The coefficient of variation of the annual precipitation record is 0.26 . The annual, monthly and seasonal oscillations of temperature and precipitation of this record have been analysed in detail (Fig. 3), and the principal climatic anomalies have been determined.

The relationships between growth and climate correlation and response function analyses were performed using the program Dendroclim 2002 (Biondi and Waikul, 2004), both for the local chronologies and for the regional chronology. Climate-growth relationships were analysed from the previous July up to October of the growth year, with the aim of identifying the meteorological variables that correlated most with tree growth. Subsequently, we analysed the relationship between the pointer years of the chronologies and climate anomalies.

\section{Results}

\subsection{Analysis of the reliability of the chronologies and compilation of the regional chronology}

Figure $4 \mathrm{a}$ shows the spatial disposition of the local chronologies with respect to the first two principal components that have been analysed. No value is anomalous, nor do any of them deviate much from the general range obtained, so all the chronologies have been accepted in carrying out this study.

The PC1 and PC2 of the chronology network were significant, representing $44.09 \%$ and $13.29 \%$ of the total variance, respectively, and the scatter plot of the PC loading coefficients displayed groups of chronologies with similar growth patterns (Fig. 4a). Although the chronologies showed different loadings with the PC1, all of them had positive correlations with it, showing that they shared a common variance. $P$. sylvestris chronologies were scattered, covering nearly the whole range of the first axis values, while the chronologies
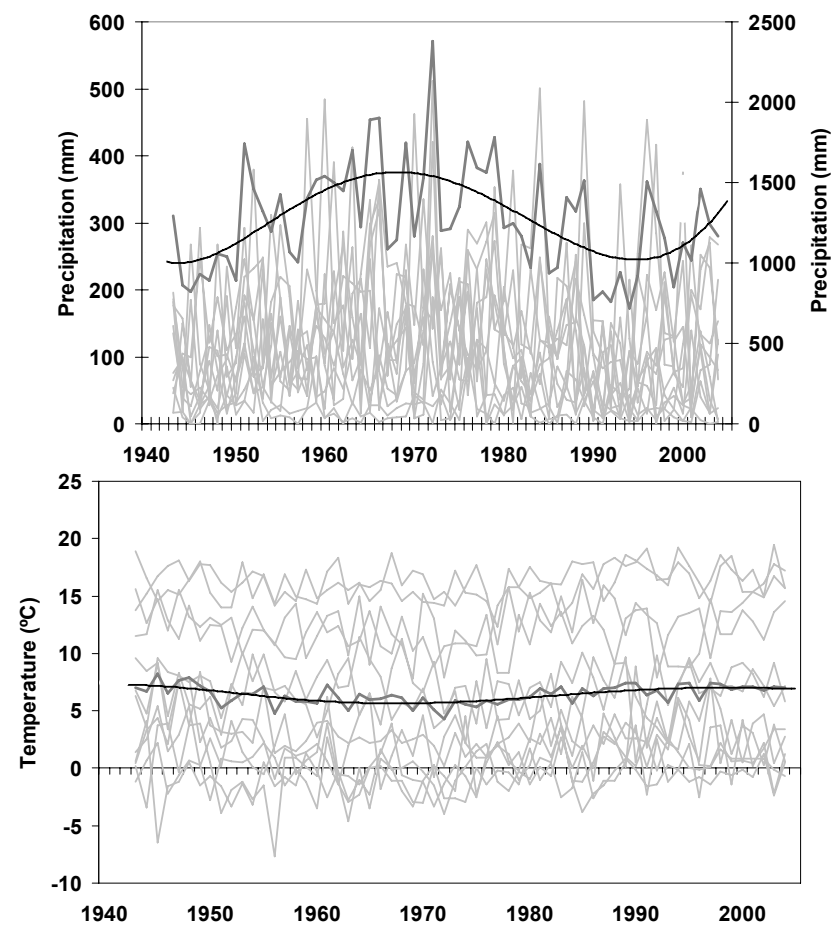

Fig. 3. (a) Temporal variability of monthly (gray solid line) and annual precipitation (dark gray solid line), and (b) monthly (gray solid line) and annual mean temperature (dark gray solid line) recorded in Navacerrada station over the time period under review; trends in annual precipitation and mean annual temperature are show (black solid line) according to a polynomial model of order 5 .

of $P$. nigra have values similar to the lower range of those reported in P. sylvestris. The differences determined in the PC1 could be related to micro-environmental diversity and, more specifically, to differences in altitude (Fig. 4b). On the other hand, one chronologies group was mainly positively correlated with the PC2, while the other was negatively correlated with it (Fig. 4a). The first corresponds with southern or eastern chronologies, the second with northern chronologies; in no case did the PC1 and PC2 show significant differences between species.

Furthermore, the discriminating values of the statistics used to analyse the reliability and significance of the time span covered by the chronologies are shown in Table 2. In some of the oldest chronologies, it has not been possible to obtain an EPS value equal or superior to 0.85 , due to the low number of individual sequences contained by said chronologies. Even so, it seemed to be of interest to us to utilise them in subsequent analyses.

Comparing the time span in which EPS is equal or superior to 0.85 and the period from which there is a correlation superior to 0.32 according to the cross-dating, it is possible to observe many cases where there are notable differences (see Table 2). It has been decided that, both for the compilation of the regional chronology and for the study of 

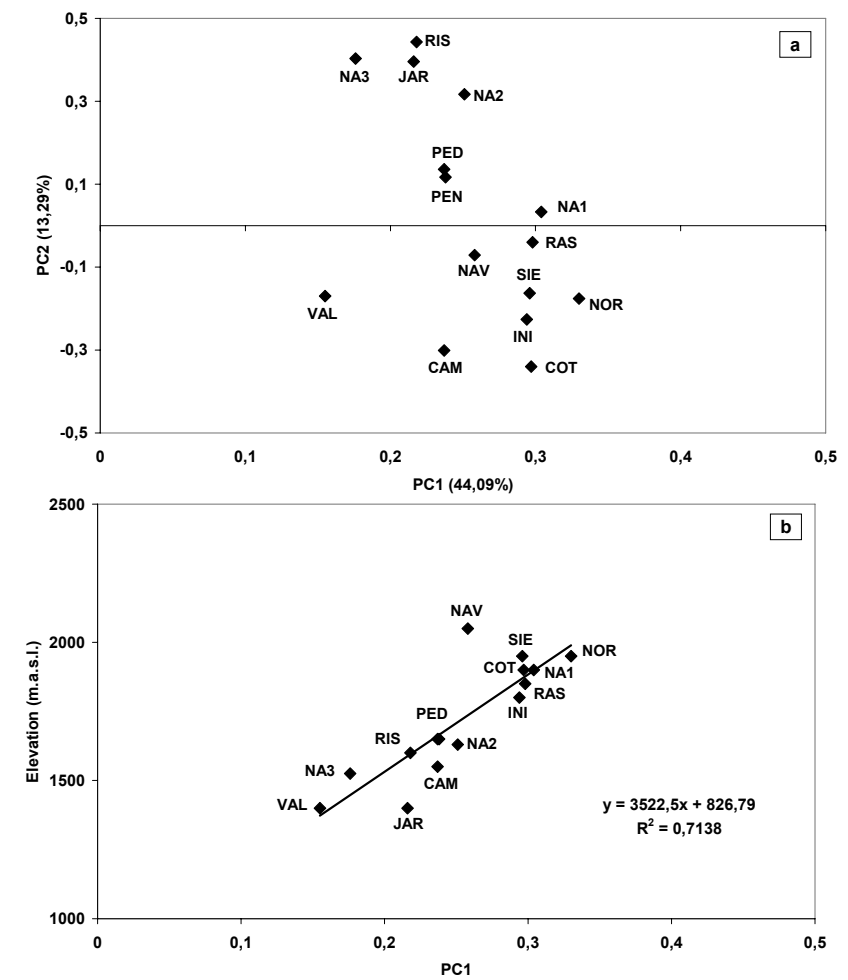

Fig. 4. (a) Scatter plots of principal component analysis (PCA) loadings of the 15 chronologies for the period 1818-1977, (b) correlation and linear regression between $\mathrm{PC} 1$ and altitude, pvalue 0.0001 .

anomalies in the width of the growth rings, the period determined by the cross-dating quality control determined by the statistical program COFECHA is reliable. Consequently, once the significance, representativity and reliability of the different sub-periods of the local chronologies were established, a representative regional chronology of the variability of the tree rings of Pinus sylvestris and Pinus nigra in the Sierra de Guadarrama could be compiled.

\subsection{Relationships between the chronologies and the meteorological record}

The relationship between the variability of the growth indices and the climate has been studied by analysing the values of the significant coefficients of the response function obtained for each local chronology and also for the regional chronology, both in relation to the analysed variables of the growth year $(n)$ and of the previous year $(n-1)$ (Fig. 5). The variables relating to precipitation, most of all in the month of August and, to a lesser degree, precipitation during the month of July (in both cases corresponding with the growth year), are those where the chronologies present the greatest sensitivity; furthermore, in the regional chronology August precipitation is alone in presenting a significant value. On the other hand, it is almost only the chronologies of Pinus nigra that present a certain relationship with the climatic variables of the previous year, as has already been pointed out in Génova and Fernández (1998-1999) and Génova et al. (1997).

\subsection{Pointer years, variability over time, and significance}

Using the criteria described in Sect. 2, extreme growth values and pointer years in individual chronologies, local chronologies and in the regional chronology have been identified. Table 3 shows only extreme growth values matching with respect to the first criterion in $75 \%$ or more of the local chronologies and which fulfil the second criterion in the regional chronology. These selected pointer years have been assigned a relative value of their significance (between \pm 1 and \pm 3 ), which likewise is shown in Table 3 and in Fig. 6 . In total, 64 pointer years have been identified: 30 negative (representing minimum growths) and 34 positive (representing maximum growths). This represents some $15 \%$ of the total number of years analysed (405 years, 1600-2005). In this same table there have also been added some references to European compilation studies for those cases where there are coincidences with the pointer years defined for the Sierra de Guadarrama. Furthermore, the climatic characteristics for these pointer years, with respect to summer precipitation, have been pointed out. As has been seen in the previous section, this is the variable most related to growth variations in the Sierra de Guadarrama. In the period 1943-2005, the data was derived from the Navacerrada record, while the information provided for the previous years proceeds from bibliographical sources, based on a variety of evidential material.

A frequent occurrence is pointer years that come together in pairs or in longer periods, constituting pointer intervals (Schweingruber et al., 1990). Among the biennial intervals, one could point out those that coincide with sign and value (1649-1650, 1707-1708, 1715-1716, 1762-1763, 17711772, 1793-1794, 1813-1814, 1814-1815, 1903-1904), or with sign, but with different values (1600-1601, 1601-1602, 1688-1689, 1737-1738, 1771-1772, 1941-1942, 19581959, 1962-1963). Other noteworthy intervals are those where various extremes are concentrated, such as the unfavourable three years from 1600-1602 and six years from 1960-1965 (the most striking in the whole register), and the favourable five years from 1734-1738 (the most striking in the whole register) and 1811-1815.

The importance of the pointer years has been studied in each century (see Fig. 6 and Table 4). The 17th and 20th centuries are those that present the highest percentage of extreme years (16\% and $23 \%$ respectively), with the last century being particularly noteworthy in this regard. With respect to variability of tree growth, the 19th century is the most homogeneous and stable, and presents a smaller number of anomalies $(11 \%)$. The distribution of anomalies, in turn, is different in each century: the 18th and 19th centuries present a similar distribution, with a third of negative extremes and two-thirds of positive extremes. For its part, the 17th century presents 


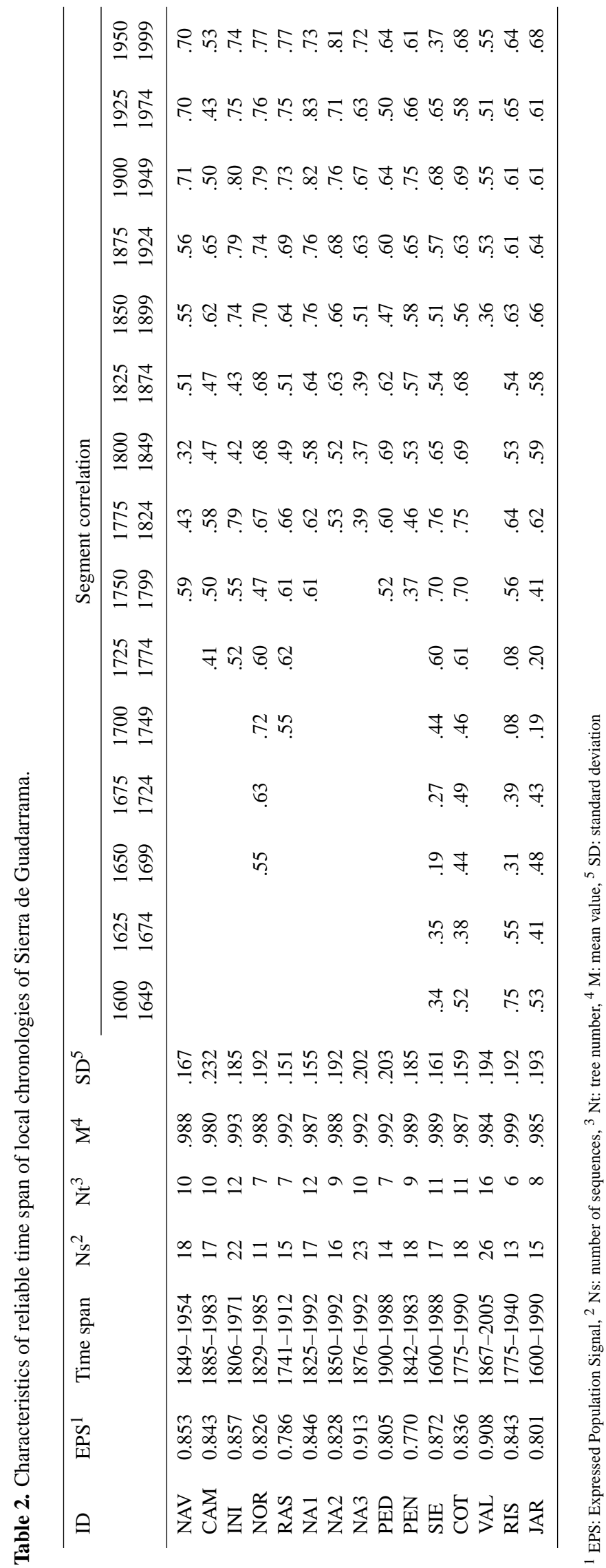


Table 3. Pointer years in Sierra de Guadarrama.

\begin{tabular}{|c|c|c|c|c|c|c|}
\hline Year & Sign & $\% \mathrm{LC}^{1}$ & $\mathrm{RGI} \pm \mathrm{DS}^{2}$ & Value $^{3}$ & Rainfall SG ${ }^{4}$ & Other European references \\
\hline 1600 & - & & $*$ & 1 & & \\
\hline 1601 & - & $100 \%$ & $* *$ & 3 & & Hantemirov et al. (2004) \\
\hline 1602 & - & $100 \%$ & $*$ & 2 & & \\
\hline 1620 & + & & $*$ & 1 & & \\
\hline 1622 & + & & $*$ & 1 & Droughts (FT1) & \\
\hline 1623 & - & $75 \%$ & & 1 & Droughts (FT1) & \\
\hline 1624 & - & $75 \%$ & $*$ & 2 & & \\
\hline 1633 & - & $75 \%$ & $*$ & 2 & High Rainfall (FT1) & \\
\hline 1645 & + & $75 \%$ & $*$ & 2 & Droughts (FT1) & \\
\hline 1646 & - & $75 \%$ & & 1 & Droughts (FT1) & \\
\hline 1649 & - & & $*$ & 1 & Droughts (FT1) & \\
\hline 1650 & - & & $*$ & 1 & Droughts (FT1) & \\
\hline 1659 & - & $75 \%$ & $*$ & 2 & Droughts (FT1) & \\
\hline 1660 & + & $75 \%$ & & 1 & & \\
\hline 1688 & - & $80 \%$ & $*$ & 2 & & \\
\hline 1689 & - & & $*$ & 1 & & \\
\hline 1707 & - & & $*$ & 1 & High Rainfall (FT2) & \\
\hline 1708 & - & & $*$ & 1 & & \\
\hline 1715 & + & & $*$ & 1 & & \\
\hline 1716 & + & & $*$ & 1 & & \\
\hline 1734 & + & & $* *$ & 3 & & \\
\hline 1737 & + & & $* *$ & 3 & & \\
\hline 1738 & + & & $*$ & 1 & Droughts (FT2) & \\
\hline 1762 & + & & $*$ & 1 & & \\
\hline 1763 & + & & $*$ & 1 & & \\
\hline 1771 & - & & $*$ & 1 & & \\
\hline 1772 & - & & $*$ & 1 & & \\
\hline 1788 & + & & $*$ & 1 & & \\
\hline 1793 & + & & $*$ & 1 & & \\
\hline 1794 & + & & $*$ & 1 & & \\
\hline 1803 & - & & $*$ & 1 & Droughts (FT2) & \\
\hline 1806 & - & & $*$ & 1 & & \\
\hline 1807 & + & $86 \%$ & & 1 & & \\
\hline 1811 & + & & $*$ & 1 & & Hantemirov et al. (2004) \\
\hline 1813 & + & & $*$ & 1 & & \\
\hline 1814 & + & & $*$ & 1 & & \\
\hline 1815 & + & & $*$ & 1 & & \\
\hline 1869 & + & & $*$ & 1 & & \\
\hline 1879 & - & & $*$ & 1 & Droughts (FT2) & Hantemirov et al. (2004) \\
\hline 1893 & + & & $*$ & 1 & & \\
\hline 1894 & - & $87 \%$ & & 1 & & \\
\hline 1903 & + & & $*$ & 1 & & \\
\hline 1904 & + & & $*$ & 1 & & \\
\hline 1914 & + & & $*$ & 1 & & \\
\hline 1921 & - & & * & 1 & Droughts (FT2) & Neuwirth et al. $(2007)( \pm)$ \\
\hline 1923 & + & $80 \%$ & $*$ & 2 & & \\
\hline 1924 & - & $100 \%$ & & 1 & & \\
\hline 1941 & - & $80 \%$ & $*$ & 2 & & Hantemirov et al. (2004) \\
\hline 1942 & - & & $*$ & 1 & & Neuwirth et al. (2007) \\
\hline 1943 & + & $80 \%$ & & 1 & Normal year & \\
\hline 1945 & + & & $*$ & 1 & Dry year & \\
\hline 1958 & + & & $*$ & 1 & Normal year & Hantemirov et al. (2004) \\
\hline 1959 & + & & $*$ & 1 & Wet year & \\
\hline 1960 & - & $80 \%$ & & 1 & Wet year & \\
\hline 1962 & - & $80 \%$ & $*$ & 2 & Wet year & Neuwirth et al. $(2007)( \pm)$ \\
\hline 1963 & - & & $* *$ & 3 & Wet year & \\
\hline
\end{tabular}


Table 3. Continued.

\begin{tabular}{ccccclc}
\hline Year & Sign & $\% \mathrm{LC}^{1}$ & $\mathrm{RGI} \pm \mathrm{DS}^{2}$ & Value $^{3}$ & Rainfall SG & Other European references \\
\hline 1964 & + & $100 \%$ & & 1 & Normal year & \\
1965 & - & & $*$ & 1 & Wet year & Neuwirth et al. $(2007)( \pm)$ \\
1973 & + & $87 \%$ & & 1 & Normal year & \\
1976 & + & & $*$ & 1 & Wet year & \\
1980 & + & & $*$ & 1 & Normal year & Hantemirov et al. $(2004)$ \\
1986 & - & $100 \%$ & $*$ & 2 & End of two dry years & \\
1994 & + & & $*$ & 1 & Driest year of the record & \\
1996 & - & & $* *$ & 3 & Wet year & Hantemirov et al., $(2004)$
\end{tabular}

$1 \%$ LC: percentage in which there is a coincidence higher than $75 \%$ among local chronologies. ${ }^{2}$ RGI \pm SD: years whose regional growth indices exceeded one or more SD (standard deviation), $1 \mathrm{SD}<{ }^{*}<2 \mathrm{SD},{ }^{* *}>2 \mathrm{SD} .{ }^{3}$ Value: relative value of the pointer year based on its significance, 1 : it is only presented in one of the two previous columns, 2 : it is presented in the two previous columns, 3: the indices values exceed 2 SD which are shown shaded. ${ }^{4}$ Rainfall SG: rating climate of the Sierra de Guadarrama in terms of rainfall, between 1943 and 1996 according to data from Navacerrada station, FT1: data extracted from Fontana Tarrats (1971-1977), FT2: data extracted from Font Tullot (1988).

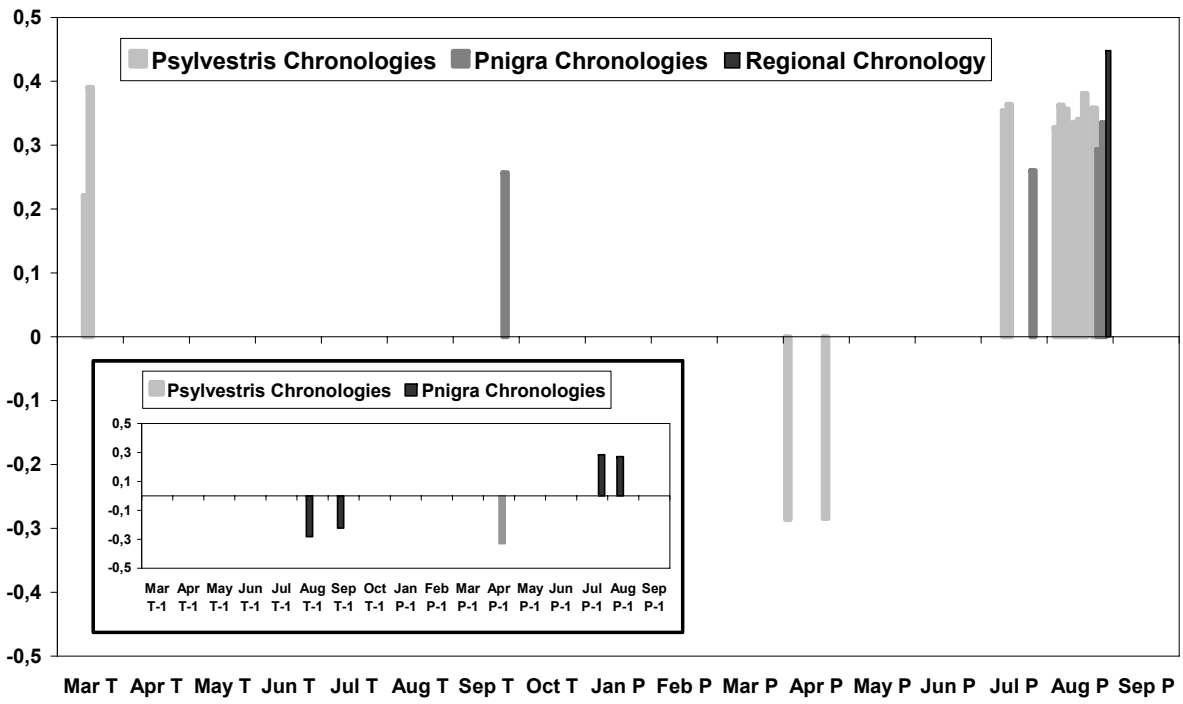

Fig. 5. Bootstrap response significant values for the year of growth (big box) and bootstrap response significant values for the previous year of growth (small box bottom left.)

the reverse of this distribution; with much more frequent negative extremes $(75 \%)$, making it consequently the most unfavourable century for growth. In the 20th century, on the other hand, the distribution between negative and positive is fairly balanced.

Both the first half of the 17th and the second half of the 20 th centuries present a great number of extreme years (19 in total), and of maximum negatives (1601, 1963 and 1996), while the years most favourable for growth are to be found in the first half of the 18th century, with few negative pointer years and only two maximum positives (1734 and 1737). Finally, it is worth pointing out that the year 1601 is the most anomalous of the whole register, with an average index of growth that is lower than the average by almost three standard deviations.

\section{Discussion}

\subsection{Pointer years and regional chronology of the Sierra de Guadarrama}

The analysis of the local chronologies compiled for the Sierra de Guadarrama has made it possible to identify a period (1600-2005) that is sufficiently reliable for the determination of extremes in the tree rings. Moreover, no significant differences have been observed between the chronologies of Pinus sylvestris and P. nigra, and all of them have been used in the compilation of a regional chronology. Both the list of pointer years augmented with respect to the data processed in Génova (2000), and the compilation of a single regional chronology can be used to synchronise and date new series of growth. A very recent demonstration of this utility has been the dendrochronological dating of historic 
Table 4. Distribution of pointer years and intervals in the four centuries analysed in Sierra de Guadarrama. The shaded years correspond to negative pointer values.

\begin{tabular}{ll}
\hline Century & Pointer years and pointer intervals \\
\hline XVII & $1600-1602,1623-1624,1633,1646,1649-1650,1659,1688-1689$ \\
& $1620,1622,1645,1660$ \\
XVIII & $1707-1708,1771-1772$ \\
& $1715-1716,1734,1737-1738,1762-1763,1788,1793-1794$ \\
XIX & $1803,1806,1879,1894$ \\
& $1807,1811,1813-1815,1869,1893$ \\
XX & $1921,1924,1941-1942,1960,1962-1963,1965,1986,1996$ \\
& $1903-1904,1914,1923,1943,1945,1958-1959,1964,1973,1976,1980,1992,1994$ \\
\hline
\end{tabular}
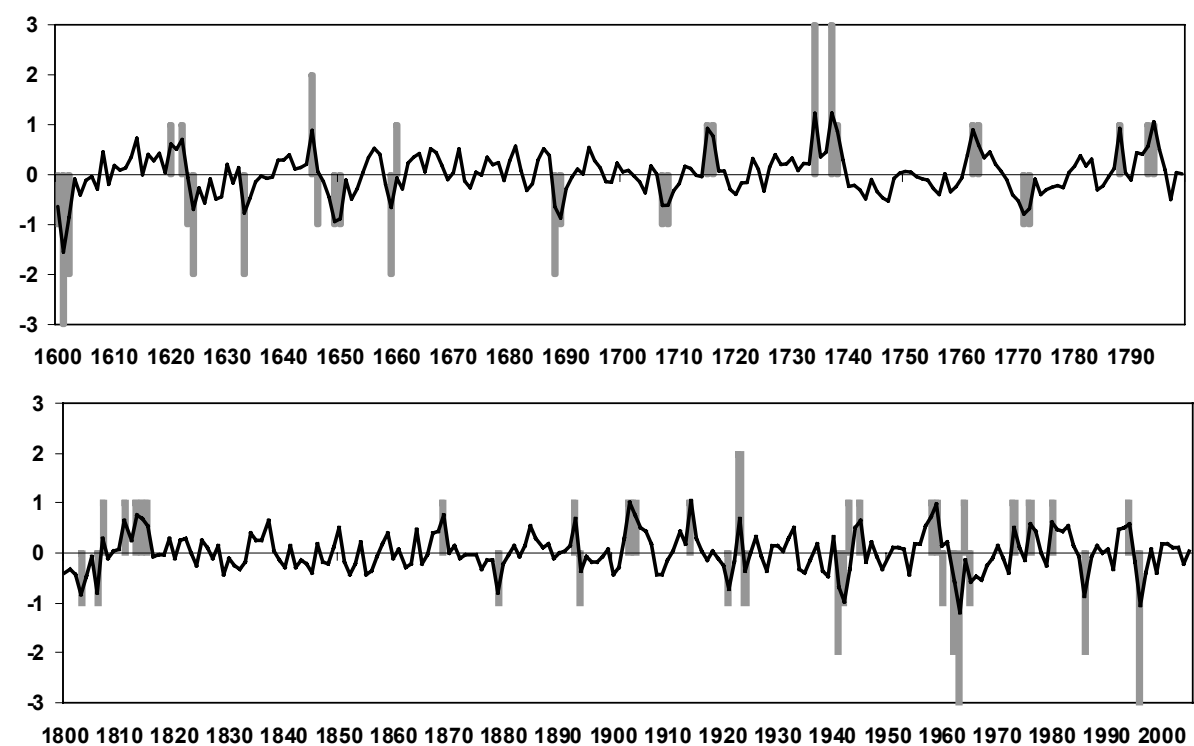

Fig. 6. Deviations to the average multiplied by 3 (to highlight best) of regional chronology of Sierra de Guadarrama (black solid line) overlying the relative value of pointer years and intervals - see 5th column in Table 3 - over the last four centuries (gray columns).

wood from the "Old Mint" in Segovia (Génova et al., 2011). This record of pointer years in Central Spain provides information regarding their significance and distribution over the last 405 years, which can be contrasted with other extensive dendrochronological records of Pinus from throughout Spain (Andreu et al., 2007; Bogino et al., 2009; Génova, 1998; Génova and Fernández, 1998-1999; Génova et al., 2009) in order to characterise anomalies of growth, indicating macroclimatic events in the Iberian Peninsula.

The year 1601 is registered in the tree rings of Central Spain as the most unfavourable for growth of the last $405 \mathrm{yr}$. As Génova (2000) already noted “... 1601 was the only year in which the indices of regional chronologies were lower than two standard deviations from the mean". This fact coincides with many other anomalies dated to this year in the tree rings of the Northern Hemisphere. For example, as Hantemirov et al. (2004) have emphasised, "Anomalous tree rings were formed in many regions in 1601. A large proportion of the samples from the Polar Urals and Yamal Peninsula have frost or light rings in 1601." Furthermore, the importance of 1601 as a pointer year for synchronising historic wood in Central Spain has very recently been pointed out by Génova et al. (2011). It was not for a long time, not until the 20th century, that other pointer years of comparable significance were identified. 1963 also represents a very significant reduction in growth, having already been cited by Richter (1988) as the only pointer year common to Pinus sylvestris in this same geographical area. It was just in the middle of the initial six years of the 1960s that, in general, constituted in the centre of Spain, an interval that was very unfavourable for tree growth (Génova, 2000). 1996 is a negative pointer year of less significance, because it is represented in the Sierra de Guadarrama by only one site, even though $100 \%$ of the trees studied there present a notable reduction in growth for that year. Hantemirov et al. (2004) also found anomalies in that year in various species of northwest Siberia. 


\subsection{Climatic significance of pointer years in the second half of the 20th century}

The anomalous meteorological years of the Navacerrada register have already been analysed in detail in Génova (2000), with the aim of establishing correlations with the extreme reductions of growth. Amplifying the temporal range of the study to 2005 , and taking into consideration also the positive extremes, it has been proved that in quite a number of cases, the anomalous meteorological years could explain the pointer years, even though a complete biunivocal correspondence does not exist.

Given that summer precipitation was found to be the most limiting factor for the growth of Pinus in the Sierra de Guadarrama in the second half of the 20th century (see Sect. 3.2), it is also an explanatory factor in almost $50 \%$ of the extreme growths. The negative pointer years 1962, 1963 and 1965 correspond more or less with dry summers in Navacerrada $(1962,1964)$ and were dry throughout Spain, according to Vicente-Serrano (2006), whereas the 1986 ring was formed after the dry year of 1985 (see Fig. 7). These results are coherent with those obtained by Lebourgeois (2000) for Pinus nigra in Western France, with many points of agreement being identified between extreme lowgrowth years and summer drought (low and high values of precipitation and temperature during the growing season).

Meanwhile, the positive 1959, 1973 and 1976 pointer years correspond with wet years. Nevertheless, other positive pointer years identified in the chronologies of the Sierra de Guadarrama - 1958, 1964, 1980 and 1994 - do not appear to have any clear climatic explanation, even when taking into account the anomalies of April temperature. This last-mentioned meteorological variable also seems to have a considerable effect on the width of the rings in Central Spain, according to Génova (2000), and could explain the positive extremes of 1943 and 1945, and also the negative extreme of 1986. Although this last pointer year has not been registered in the most recent European compilations, Lebourgeois (2000) does draw attention to it in the chronologies of Pinus nigra in Western France, indicating that it cannot be associated with a rainfall deficit, but seems to be linked to extreme frost in February.

1996 was a year of extreme reduction in growth, and even though we only have data corresponding with one site (Valsaín), $100 \%$ of the trees present a narrow ring for that year. It could be the outcome of the snow and wind storm of January 1996, which caused damage extending over 6600 ha of the area (more than $80 \%$ of the forest's total surface), and leading to the cutting of an enormous amount of wood - the most in the last $50 \mathrm{yr}$, according to Donés and Garrido (2001)-. This year was anomalous to the normal development of the cambium, due to the branches breaking under the weight of snow (J. Donés, personal communication, 2007). Furthermore, even though neither that year nor the previous ones were notably dry in summer, the six years from

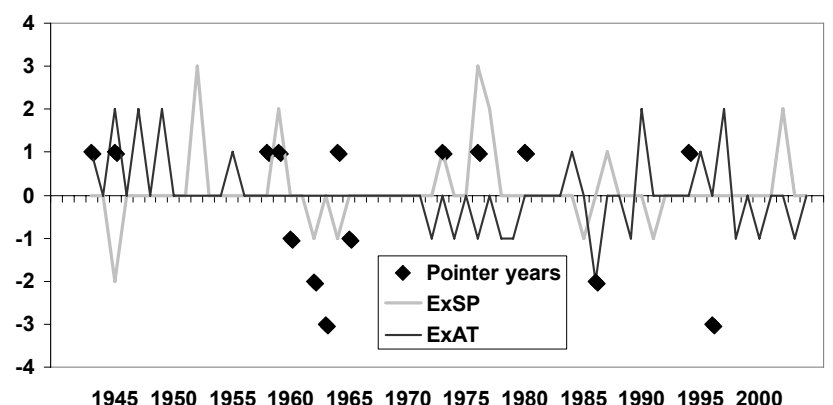

Fig. 7. Pointer years (diamonds) of Sierra de Guadarrama and selected extreme climate years (solid line) of Navacerrada station. ExSP: extreme summer precipitation standardized, ExAT: extreme April temperatures standardized.

1990-1995 constitute the driest period of the whole meteorological register as far as annual precipitation is concerned. Indeed, the decade of the 1990s was noteworthy for having seen one of the more extreme droughts that affected a major part of the Peninsula (Vicente-Serrano, 2006), and in other regions of Spain, 1995 is a pointer year related to this driest period as, for example, in chronologies of Abies pinsapo in south Iberian mountains (Génova, 2007). Quite possibly the lack of phreatic water affected the formation of the 1996 ring in Valsaín, combined with the storm damage. Once more data are available, it will be possible to compare and determine whether this event was local or more general.

\subsection{Temporal distribution of pointer years and their significance in Central Spain}

Our results show that pointer years and intervals are not evenly distributed throughout time; instead, both in the 17th and 20th centuries, the macro-climatic anomalies that affected growth were more frequent and more extreme than in the other two centuries analysed. This dendroclimatic characterisation of the last four centuries of the last millennium, based on the distribution and significance of the pointer years and intervals, coincides in general terms with the historic data relating to the Iberian Peninsula climate compiled by Fernández and Manrique (1997). These authors analysed the amount of data available in each decade relating to droughts, heavy rainfall and flooding, severe cold, frosts and high temperatures, from the years 1100 to 1900 . Their conclusion, even having taken into account the subjectivity relating to this type of information, is that the period from 1500 to 1700 presents a greater amount of news relating to climatic extremes than the two subsequent centuries. This enables them to identify with some precision the length and the characteristics of the Little Ice Age (LIA) in Spain, which drew to an end at the beginning of the 18th century. Numerous studies of historical climatology carried out subsequently in Spain are laying the methodological groundwork for an 
objective record of the historical news relating to the climate (Barriendos, 1997; Domínguez-Castro et al., 2010; Rodrigo and Barriendos, 2008). As far as Central Spain is concerned, these events are expressed in the work of Bullón (2008), and Domínguez-Castro et al. (2008).

Negative pointer years are much more abundant over the 17 th century, particularly in its first half, which presents the highest concentration of extreme negative years for tree growth $(9 \mathrm{yr})$. By contrast, in the 18th century there are abundant positive extremes, indicating a period that is generally favourable for the growth of trees. These results only partially match the reconstruction of drought episodes for Central Spain from rogation ceremonies (Domínguez-Castro et al., 2008). In this paper were indicated two drought maxima, the 1600-1675 and 1711-1775 periods; however, in the latter the tree rings do not show significant anomalies. By contrast, they match a middle stage (1676-1710) when droughts were less frequent and short (Domínguez-Castro et al., 2008), and the hypothesis that the Maunder Minimum (1645-1715) marks the transition from the dry conditions of the sixteenth and early seventeenth century to the longest wet period in the Iberian Peninsula, between 1670-1765 (Domínguez-Castro et al., 2010). The 19th century presents very few pointer years and seems to have been very favourable for growth, matching the few droughts all below the average of the rogation series (Domínguez-Castro et al., 2008). It could be that the more frequent negative $\mathrm{NAO}$ atmospheric conditions during the 18th and 19th centuries (Luterbacher et al., 2002; Pauling et al., 2006) explain the preponderance of damp conditions over that period.

The second half of the 20th century and the first half of the 17th century together constitute the two most notable periods for the frequency of negative pointer years in Central Spain. This was particularly the case during the decade of the 1960s, which saw an almost continuous period of six years where the indices of growth were below average. Even though specific years are not referred to, this same period is clearly reflected in Fig. 4 of the extensive study of Andreu et al. (2007), with chronologies from the north and east of the Iberian Peninsula. Nevertheless, this period does not appear to have had the same significance in other European areas, since only 1962 and 1965 appear indicated as pointer years by Neuwirth et al. (2007), with 1965 representing positive and negative anomalies, depending on the region. Andreu et al. (2007) claim that the higher occurrence in Spain of extreme years and the sensitivity increase in the second half of the 20th century were in agreement with an increment in precipitation variability during the growing period, which has been highlighted by Font Tullot (1988), Romero et al. (1998), De Luis et al. (2000) and Giorgi et al. (2004). VicenteSerrano (2006) points out that the most intense droughts were recorded in the 1940s, 1950s, 1980s and 1990s. Thus, the negative pointer interval of 1960s does not appear to be any clear explanation on the basis of these data; other sources could provide more explanation in future studies.

\subsection{Events of special relevance}

The interval 1600-1602 is one of the most unfavourable for tree growth in the centre of Spain, and 1601 is the minimum index in the regional chronology. As has already been pointed out, this coincides with many other anomalies dated to that year in the tree rings of the Northern Hemisphere. Hantemirov et al. (2004) correlated these anomalies with some global event that left its trace in the tree rings of woody plants. According to Briffa et al. (1998), 1601 was the most severe short-term Northern Hemisphere cooling event of the past 600 years. Continuing with an already long tradition that matches the major volcanic eruptions to growth reduction or other anomalies in tree rings (e.g. LaMarche and Hirschboeck, 1984; Scuderi, 1990; Jones et al., 1995, among others), it is possible to infer that this extreme pointer year was the effect of the eruption of Huaynaputina, which occurred in Peru at the beginning of 1600 AD (Briffa et al., 1998). According to these seen growth anomalies and to other proxies, this was the biggest eruption in the world in the last 600 years (Briffa et al., 1998, de Silva and Zielinski, 1998; Hantemirov et al., 2004). Nevertheless, this is the first time that the effects of this eruption in the tree-ring records of Southern Europe have been demonstrated. It needs to be emphasised, moreover, that the effects of this volcanic eruption were registered in the Sierra de Guadarrama as a pointer interval during a whole three years, from the starting year, 1600 , until 1602. On the other hand, there has been no evidence of the effects of other more recent eruptions in the chronologies that have been analysed.

While the authors who have analysed this particular macro-climatic event and its consequences for tree growth have attributed its effects to the severe cooling event (Hantemirov et al., 2004; Briffa et al., 1998), some climatic reconstructions of the central Iberian Peninsula have also indicated that the start of the 17th century was very dry (Domínguez-Castro et al., 2008). It could be that this volcanic eruption caused the climatic anomalies in this period in Central Spain, or it could also be that its effects on tree growth are more related to the reduction of solar energy, due to the accumulation of ash in the atmosphere, and the consequent diminution of photosynthesis. This hypothesis could explain the pointer interval at the start of the 1960s, although we know that no large-scale eruptions were recorded in this period; therefore, the accumulation of ash and other particles in the atmosphere could be of anthropic origin (pollution, atomic weapons testing, etc.).

Acknowledgements. With gratitude to all those colleagues and friends who encouraged me to write this paper which has been hanging over me for so long, especially Marga Costa and Andrés Díez. Thanks to Louis Ryan, who translated it into English, and to Aitor Gaston who helped me with Fig. 1. The translation and edition of this paper was funded by the Spanish Ministerio de Ciencia e Innovación (project CGL2008-06005). I also thank Emilia Gutiérrez and Javier Martín-Vide (the two reviewers) for 
their comments and critical remarks, their suggestions considerably improved this paper.

Edited by: D. Wheeler

\section{References}

Andreu, L., Gutierrez, E., Macias, M., Ribas, M., Bosch, O., and Camarero, J. J.: Climate increases regional tree-growth variability in Iberian pine forests, Global Change Biol., 13, 804-815, doi:10.1111/j.1365-2486.2007.01322.x, 2007.

Barriendos, M.: Climatic variations in the Iberian peninsula during the late Maunder minimum (AD 1675-1715): an analysis of data from rogation ceremonies, Holocene, 7, 105-111, doi:10.1177/095968369700700110, 1997.

Bauer, E.: Los Montes de España en la historia, Ministerio de Agricultura, Madrid, 1980.

Benso, M.: Estudio dendrocronológico de Pinus sylvestris L. en los Montes de Valsaín (Segovia), Proyecto Fin de Carrera, Universidad Politécnica de Madrid, 2007.

Biondi, F. and Waikul, K.: Dendroclim 2002: a C++ program for statistical calibration of climate signals in tree-ring chronologies, Comput. Geosci., 30, 303-311, 2004.

Bogino, S., Fernández Nieto, M. J., and Bravo, F.: Climate effect on radial growth of Pinus sylvestris at its southern and western distribution limits, Silva Fennica, 43, 609-623, 2009.

Bräker, O. and Schweingruber, F.: Standorts- chronologien, Teil 1: Iberische Halbinsel, Publikation der Forstl. Vers. Anst. Birmendorsf, 73 pp., 1984.

Briffa, K. R., Jones, P. D., Schweingruber, F. H., and Osborn, T. J.: Influence of volcanic eruptions on Northern Hemisphere summer temperatures over 600 years, Nature, 393, 450-455, doi:10.1038/30943, 1998.

Bullón, T.: Winter temperatures in the second half of the sixteenth century in the central area of the Iberian Peninsula, Clim. Past, 4, 357-367, doi:10.5194/cp-4-357-2008, 2008.

De Luis, M., Raventós, J., González-Hidalgo, J. C., Sánchez, J. R., and Cortina, J.: Spatial analysis of rainfall trends in the region of Valencia (East Spain), Int. J. Climatol., 20, 1451-1469, 2000.

De Silva, S. L. and Zielinski, G. A.: Global influence of the AD 1600 eruption of Huaynaputina, Peru, Nature, 393, 455-458, 1998.

Domínguez-Castro, F., Santisteban, J. I., Barriendos, M., and Mediavilla, R.: Reconstruction of drought episodes for central Spain from rogation ceremonies recorded at Toledo Cathedral from 1506 to 1900: A methodological approach, Global Planet. Change, 63, 230-242, doi:10.5194/cpd-6-1111-2010, 2008.

Domínguez-Castro, F., García-Herrera, R., Ribera, P., and Barriendos, M.: A shift in the spatial pattern of Iberian droughts during the 17th century, Clim. Past, 6, 553-563, doi:10.5194/cp-6-5532010, 2010.

Donés, J. and Garrido, M.: Daños por temporales en el monte pinar de Valsaín. Datos históricos y problemas generados por el temporal de enero de 1996, in: Proceedings of the III Congreso Forestal Español, Granada, September 2001, VII-X, 315-320, 2001.

Elferts, D.: Scots pine pointer-years in northwestern Latvia and their relationship with climatic factors, Acta Univ. Latv., 723, 163-170, 2007.
Fernández, A. and Manrique, E.: Nueva metodología para la reconstrucción dendroclimática y aplicaciones más importantes, INIA, Madrid, 127 pp., 1997.

Font Tullot, I.: Historia del clima en España, Instituto Nacional de Meteorología, Madrid, Spain, 1988.

Fontana Tarrats, J. M.: Entre El cardo y la rosa, Historia del clima en las mesetas, Madrid, Unedited typewritten work, 1971-1977.

Génova, M.: Estudio de los anillos de crecimiento y su relación con las variables meteorológicas en el pinar de Lillo (León), Ecologa, 12, 237-250, 1998.

Génova, M.: Anillos de crecimiento y años característicos en el Sistema Central (España) durante los últimos cuatrocientos años, Boletín de la Real Sociedad de Historia Natural, 96, 33-42, 2000.

Génova, M.: El crecimiento de Abies pinsapo y el clima de Grazalema: aportaciones dendroecológicas, Investigación agraria, Sistemas y Recursos Forestales, 16, 145-157, 2007.

Génova, M.: Cronologías milenarias de anillos de crecimiento, in: Los bosques de Gredos a través del tiempo, Junta de Castilla y León, Valladolid, 151-177, 2009.

Génova, M. and Fernández, A.: Tree rings and climate of Pinus nigra subsp. salzmannii in Central Spain, Dendrochronologia, 1617, 75-86, 1998/1999.

Génova, M., Fernández Cancio, A., and Creus, J.: Diez series medias de anillos de crecimiento en los sistemas Carpetano e Ibérico, Investigación agraria. Sistemas y Recursos Forestales, 2, 151-172, 1993.

Génova, M., Fernández, A., and Creus, J.: Análisis dendroclimático del crecimiento de Pinus sylvestris y Pinus nigra en la Sierra de Guadarrama, in: Proceedings of the I Congreso Forestal hispanoluso, Pamplona, Navarra, June 1997, I-II, 75-80, 1997.

Génova, M., Benso, M., and Moya, P.: Análisis de la dinámica forestal registrada en los anillos de crecimiento, in: Proceedings of the V Congreso Forestal Español, 5CFE01-021, Avila, 21-25 September 2009.

Génova, M., Ballesteros-Cánovas, J. A., Díez-Herrero, A., and Martínez-Callejo, B.: Historical Floods and Dencrochronological Dating of a Wooden Deck in the Old Mint of Segovia, Spain, Geoarchaelogy, 26, 786-808, doi:10.1002/gea.20369, 2011.

Giorgi, F., Bi, X., and Pal, J. S.: Mean, interannual variability and trends in a regional climate change experiment over Europe, I. Present-day climate (1961-1990), Clim. Dynam., 22, 733-756, doi:10.1007/s00382-004-0409-x, 2004.

Hantemirov, R. M., Gorlanova, L. A., and Shiyatov, S. G.: Extreme temperature events in summer in northwest Siberia since AD742 inferred from tree rings, Palaeogeography, Palaeoclimatology, Palaeoecology, 209, 155-164, doi:10.1016/j.palaeo.2003.12.023, 2004.

Holmes, R.: Dendrochronology Program Library. Installation and Program Manual, Laboratory of Tree-Ring Research, University of Arizona, USA, 1992.

Holmes, R.: Users manual for Program Cofecha by Laboratory of Tree-Ring Research, University of Arizona, Tucson, Arizona, USA, 1999.

Jones, P. D., Briffa, K. R., and Schweingruber, F. H.: Tree-ring evidence of the widespread effects of explosive volcanic eruptions, Geophys. Res. Lett., 22, 1333-1336, 1995.

Kienast, F., Schweingruber, F., Bräker, O., and Schär, E.: Tree-ring studies on conifers along ecological gradients and the potential of single-year analyses, Can. J. Forest. Res., 17, 683-696, 1987. 
Knapp, P. A., Grissino-Mayer, H. D., and Soule, P. T.: Climate regionalization and the spatio-temporal occurrence of extreme single-year drought events (1500-1998) in the interior Pacific Northwest, USA, Quaternary Res., 58, 226-233, doi:10.1006/qres.2002.2376, 2002.

LaMarche, V. C. and Hirschboeck, K. K.: Frost rings in trees as records of major volcanic eruptions, Nature, 307, 121-126, 1984.

Lebourgeois, F.: Climatic signals in earlywood, latewood and total ring width of Corsican pine from western France, Ann. Forest. Sci., 57, 155-164, 2000.

Luterbacher, J., Xoplaki, E., Dietrich, D., Jones, P. D., Davies, T. D., Portis, D., González-Rouco, J. F., von Storch, H., Gyalistras, D., Casty, C., and Wanner, H.: Extending North Atlantic Oscillation reconstructions back to 1500 , Atmos. Sci. Lett., 2, 114-124, 2002

Manrique, E. and Fernández-Cancio, A.: Extreme climatic events in dendroclimatic reconstructions from Spain, Climatic Change, 44, 123-138, 2000.

Martín-Vide, J. and Barriendos, M.: The use of rogation ceremony records in climatic reconstruction: a case study from Catalonia (Spain), Climatic Change, 30, 201-221, 1995.

Martínez García, F. and Costa, M.: La interpretación de los bosques de Pinus sylvestris L. del sistema central español en la literatura geobotánica y forestal, Bol R. Soc. Esp. Hist. Nat. Actas, 96, 27-68, 2001.

Meyer, F. D.: Pointer year analysis in dendroecology: A comparison of methods, Dendrochronologia, 16-17, 193-204, 1999.

Neuwirth, B., Schweingruber, F. H., and Winiger, M.: Spatial patterns of central European pointer years from 1901 to 1971, Dendrochronologia, 24, 79-89, 2007.

Pauling, A., Luterbacher, J., Casty, C., and Wanner, H.: Five hundred years of gridded high-resolution precipitation reconstructions over Europe and the connection to largescale circulation, Clim. Dynam., 26, 387-405, doi:10.1007/s00382-005-0090-8, 2006.

Querrec, L., Filion, L., Auger, R., and Arseneault, D.: Tree-ring analysis of white cedar (Thuja occidentalis L.) archaeological and historical wood in Quebec City (Quebec, Canada), Dendrochronologia, 27, 199-212, 2009.

Regato, P., Génova, M., and Gómez, F.: Las representaciones relictas de Pinus nigra Arnold en el Sistema Central Español, Boletín de la Real Sociedad española de Historia Natural, S.B., 88, 6371, 1992.

Richter, K.: Dendrochronologische und Dendroklimatologische Untersuchungen an kiefern (Pinus sp.) in Spanien, Diss. University of Hamburg, Germany, 1988.

Rodrigo, F. S. and Barriendos, M.: Reconstruction of seasonal and annual rainfall variability in the Iberian peninsula (16th20th centuries) from documentary data, Global Planet. Change, 63, 243-257, doi:10.1016/j.gloplacha.2007.09.004, 2008.
Rodrigo, F. S., Esteban-Parra, M. J., Pozo-Vázquez, D., and CastroDíez, Y.: A 500-year precipitation record in Southern Spain, Int. J. Climatol., 19, 1233-1253, 1999.

Rojo, A. and Montero, G.: El pino silvestre en la Sierra de Guadarrama. Ministerio de Agricultura, Pesca y Alimentación, Madrid, Spain, 1996.

Rolland, C., Desplanque, C., Michalet, R., and Schweingruber, F. H.: Extreme tree rings in spruce (Picea abies [L.] Karst.) and fir (Abies alba Mill.) stands in relation to climate, site, and space in the southern French and Italian Alps, Arct. Antarct. Alp. Res. 32, 1-13, 2000.

Romero, R., Guijarro, J. A., Ramis, C., and Alonso, S.: A 30-year (1964-1993) daily rainfall data base for the Spanish Mediterranean regions: first exploratory study, Int. J. Climatol., 18, 541560, 1998.

Saz, M.: Temperaturas y precipitaciones en la mitad norte de España desde el siglo XV, Estudio dendroclimático, Publicaciones del Consejo de Protección de la Naturaleza de Aragón, Zaragoza, 2003.

Schweingruber, F., Eckstein, D., Serre-Bachet, F., and Bräker, O.: Identification, Presentation and Interpretation of Event Years and Pointer Years in Dendrochronology, Dendrochronologia, 8, 938, 1990.

Schweingruber, F. H.: Dendroecological information in pointer years and abrupt growth changes, in: Methods of Dendrochronology: Applications in the Environmental Sciences, International Institute for Applied Systems Analysis, Kluwer Academic Publishers, Boston, USA, 277-284, 1990.

Scuderi, L. C.: Tree-ring evidence for climatically effective volcanic eruptions, Quaternary Res., 34, 67-85, 1990.

Vicente-Serrano, S. M.: Spatial and temporal analysis of droughts in the Iberian Peninsula (1910-2000), Hydrolog. Sci. J., 51, 8397, 2006.

Vicente-Serrano, S. M. and Cuadrat, J. M.: North Atlantic oscillation control of droughts in north-east Spain: evaluation since 1600 A.D., Climatic Change, 85, 357-379, doi:10.1007/s10584007-9285-9, 2007.

Wigley, T. M. L., Briffa, K. R., and Jones, P. D.: On the average value of correlated time series, with applications in Dendroclimatology and Hydrometeorology, J. Clim. Appl. Meterol., 23, 201-213, 1984.

Yuste, I.: Estudio dendrocronologico del Pinus sylvestris L. en el monte no 198 del CUP de los de Segovia, Pinar de Navafria, Proyecto Fin de Carrera, Universidad Politécnica de Madrid, Spain, 1994. 